\title{
Functional feeding groups of aquatic insect families in Latin America: a critical analysis and review of existing literature
}

\author{
Alonso Ramírez ${ }^{1} \&$ Pablo E. Gutiérrez-Fonseca ${ }^{2}$ \\ 1. Department of Environmental Sciences, University of Puerto Rico, P.O. Box 190341, San Juan, Puerto Rico 00919; \\ aramirez@ramirezlab.net \\ 2. Department of Biology, University of Puerto Rico Rio Piedras, San Juan, Puerto Rico 00919; gutifp@gmail.com
}

Received 12-XII-2013. Corrected 20-I-2014. Accepted 13-II-2014.

\begin{abstract}
Aquatic macroinvertebrates are involved in numerous processes within aquatic ecosystems. They often have important effects on ecosystem processes such as primary production (via grazing), detritus breakdown, and nutrient mineralization and downstream spiraling. The functional feeding groups (FFG) classification was developed as a tool to facilitate the incorporation of macroinvertebrates in studies of aquatic ecosystems. This classification has the advantage of combining morphological characteristics (e.g., mouth part specialization) and behavioral mechanisms (e.g., way of feeding) used by macroinvertebrates when consuming resources. Although recent efforts have greatly advanced our ability to identify aquatic macroinvertebrates, there is limited information on FFG assignment. Furthermore, there has been some variation in the use of the FFG classification, in part due to an emphasis on using gut content analysis to assign FFG, which is more appropriate for assigning trophic guilds. Thus, the main goals of this study are to (1) provide an overview of the value of using the FFG classification, (2) make an initial attempt to summarize available information on FFG for aquatic insects in Latin America, and (3) provide general guidelines on how to assign organisms to their FFGs. FFGs are intended to reflect the potential effects of organisms in their ecosystems and the way they consume resources. Groups include scrapers that consume resources that grow attached to the substrate by removing them with their mouth parts; shredders that cut or chew pieces of living or dead plant material, including all plant parts like leaves and wood; collectors-gatherers that use modified mouth parts to sieve or collect small particles $(<1 \mathrm{~mm})$ accumulated on the stream bottom; filterers that have special adaptations to remove particles directly from the water column; and predators that consume other organisms using different strategies to capture them. In addition, we provide details on piercers that feed on vascular plants by cutting or piercing the tissue using sharp or chewing mouth parts and consume plant liquids. We also provide a list of families of aquatic insects in Latin America, with an initial assignment to FFGs. We recommended caution when assigning FFGs based on gut contents, as it can provide misleading information. Overall, FFG is a very useful tool to understand the role of aquatic macroinvertebrates in stream ecosystems and comparisons among studies will benefit from consistency in their use. Rev. Biol. Trop. 62 (Suppl. 2): 155-167. Epub 2014 April 01.
\end{abstract}

Key words: food habits, FFG, trophic guilds, trophic structure, tropical streams.

Aquatic macroinvertebrates play important roles in many ecological processes in their ecosystems. Processes like the breakdown of leaf litter are mediated by the presence of invertebrates that cut or chew pieces of leaf material (Wallace, Webster \& Cuffney, 1982; Cuffney, Wallace \& Lugthart, 1990). Rates of leaf breakdown are often faster in the presence of invertebrates than when they are reduced in numbers, in particular in small streams (Webster \& Benfield, 1986). In addition, macroinvertebrates that consume algal resources have important impacts on algal biomass and primary production (Lamberti \& Resh, 1983). Grazing by macroinvertebrates is also beneficial to microbes, as they recycle nutrients back into the environment (Vanni, 2002). As primary consumers in aquatic food 
webs, macroinvertebrates represent an important link between basal resources (e.g., algae and detritus) and upper trophic levels (e.g., fish) or microbial communities (Díaz Villanueva, Albariño \& Canhoto, 2012). However, their role is not only to make energy available to upper trophic levels, they also regulate energy flow along the aquatic food web (Chew, 1974; Wallace \& Webster, 1996).

The function of particular macroinvertebrates in their ecosystems can be best understood by describing their activities and preferred resources. The ecological function of a species population in an ecosystem process is the result of their feeding activities and the mechanisms used to consume their food resources (Wallace \& Webster, 1996). The use of functional feeding groups (FFG) was introduced by Cummins and collaborators (Cummins, 1973; Cummins \& Klug, 1979) as a tool to facilitate the incorporation of macroinvertebrates in studies of aquatic ecosystem processes. This classification has the advantage of combining morphological characteristics (e.g., mouth part specialization) and behavioral mechanisms (e.g., way of feeding) used by macroinvertebrates when consuming resources (Cummins \& Klug, 1979). Classic examples include the role of insect shredders (e.g., organisms that facilitate the breakdown of leaves) in contributing to the processes of organic matter decomposition (Cummins, Wilzbach, Gates, Perry \& Taliaferro, 1989) and also in generating fine particles that are transported downstream or accumulate in the bottom and are used by other consumers, such as collectors (Cummins \& Klug, 1979).

Studies on ecosystem processes in tropical streams face multiple obstacles. Taxonomic information is often cited as a limiting factor, but recent efforts have greatly advanced our ability to identify aquatic macroinvertebrates (e.g., Domínguez \& Fernández, 2009 for South America; Springer, Ramírez \& Hanson, 2010, for Central America). However, studies on ecosystem processes are still facing limited information on macroinvertebrate FFG assignment. This lack of information is not surprising as FFG assignment requires information on the organism behavior and morphology, which we often lack. Often, tropical studies have used information from temperate regions to assign FFG to tropical taxa (e.g., Ramírez \& Pringle, 1998). However, several efforts to advance our understanding of the feeding ecology of tropical macroinvertebrates have been made, including Cummins, Merritt \& Andrade (2005). Jackson \& Sweeney (1995) reared insects from Costa Rica and assigned them to FFG based on their selected food resource and feeding mechanisms. More recently, studies in South America studying the gut content of macroinvertebrates have made an effort to assign them to FFG (e.g., Tomanova, Goitia \& Helesic, 2006; Chará-Serna, Chará, Zúniga, Pearson \& Boyero, 2010; Chará-Serna, Chará, Zúniga, Pedraza \& Giraldo, 2012).

There has always been some degree of variation in the use and assignment of FFGs (Palmer \& O'Keeffe, 1992), and some tropical studies also depart from the traditional use of FFG (sensu Cummins, 1973) by assigning groups based on information on food items consumed, rather than a combination of food selection and feeding mechanism. While those studies provide valuable information and greatly advance our understanding of tropical ecosystems, the use of different methods might hinder our ability to identify general patterns and make comparisons among streams and regions. In this context, we prepared this review of the FFG concept to clarify its categories, its proper use, and the way in which organisms should be assigned to categories. We divide the review in three main parts: (1) an overview of the FFG classification (sensu Cummins, 1973), (2) an attempt at summarizing published information on FFG for aquatic insects in Latin America, and (3) general guidelines on how to properly assign organisms to their FFG. Rather than providing new information, our goal is to compile available information on FFG that is currently disperse in a diversity of publications, in hopes to help advance our understanding of tropical stream ecosystems. 


\section{Functional Feeding groups}

The FFG classification was developed by Cummins (1973) and adopted in multiple ecological projects. In particular, this classification system played a key role in the development of the River Continuum Concept (Vannote, Minshall, Cummins, Sedell \& Cushing, 1980), a concept that greatly advanced our understanding of stream ecology in temperate and tropical regions. The FFG classification system was not extensively developed in the original publication and has generated some degree of discussion and confusion as well. However, the main goal of this classification is to aid in understanding the role that macroinvertebrates play in ecosystem functions. Some of the ecosystem functions where macroinvertebrates play an important role include control of primary production, detritus breakdown, and nutrient mineralization and downstream spiraling.

Here we summarize FFGs based on the premise that they are the result of two key aspects of macroinvertebrates: morphological characteristics related to acquiring food resources (e.g., mouth parts and related structures) and behavioral mechanisms (e.g., feeding behavior). This is the same premise originally used by Cummins (1973) when defining FFGs and by Wallace and Webster (1996) in their review of the role of macroinvertebrates in stream ecosystems.

Scrapers: Scrapers are organisms that consume resources that grow over substrates by removing them with their mouth parts, which are adapted to crop particles closely attached to rocks and other substrates. Scrapers consume a diversity of resources, including algae attached to rocks, benthic biofilms that are composed of bacteria, fungi, algae and their matrix of polysaccharides, which cover hard substrates in aquatic ecosystems (Lock, Costerton, Ventullo, Wallace \& Charlton, 1984).

Scrapers are abundant in stream ecosystems and by consuming algae can have important effects on primary producers. Feminella \& Hawkins (1995) conducted a meta-analysis of studies assessing the role of invertebrates as primary consumers in stream ecosystems, concluding that they play an important role consuming producer biomass and that they also affect algal species composition. It should be noted that different densities of scrapers can result in a range of positive to negative effects on algal biomass and production (Feminella \& Hawkins, 1995; Barbee, 2005).

Suggested translation to Spanish: raspadores.

Piercers: Piercers are organisms that feed on vascular plants by cutting or piercing the tissue using sharp or chewing mouth parts and consume plant liquids. Small caddisfly species, like certain Hydroptilidae, are known to pierce individual algal cells to consume cellular fluids avoiding the consumption of cellulose-rich cell walls (Swanson, Hrinda \& Keiper, 2007). This category was not included as a separate one in the initial groups proposed by Cummins, but was later added in the first edition of the manual of North American aquatic insects (Merritt \& Cummins, 1978). There are few studies assessing the ecological roles of piercing macroinvertebrates. However, organisms such as larval Hydroptilidae tend to be abundant in streams and might be expected to have important effects on algal communities.

Suggested translation to Spanish: perforadores.

Shredders: Shredders are organisms that cut or chew pieces of living or dead plant material, including all plant parts like leaves and wood. The main function of shredders is the breakdown of large particles of plant material into smaller pieces that are then transported downstream or available to other stream consumers (Wallace \& Webster, 1996). Shredders also make nutrients available to microbial consumers (Díaz Villanueva et al., 2012). In general, we refer to them as consumers of coarse particulate organic matter (CPOM) and producers of fine particulate organic matter (FPOM). Shredders of living plant material (Sh-Hb in Table 1) are herbivores and miners, 
TABLE 1

List of Latin American aquatic insect families and their FFGs assigned based on available information

\begin{tabular}{|c|c|c|}
\hline Order / Family & Functional Feeding Group & Reference \\
\hline \multicolumn{3}{|l|}{ Ephemeroptera } \\
\hline Ameletopsidae & $\operatorname{Pr}$ & Domínguez \& Fernández (2009) \\
\hline Baetidae & Generally CG, Baetodes SC & Baptista et al. (2006); Merritt et al. (2008) \\
\hline Caenidae & CG & Merritt et al. (2008) \\
\hline Coloburiscidae & $\mathrm{Ft}$ & Wisely (1961) \\
\hline Coryphoridae & Unknown & \\
\hline Ephemeridae & CG & Merritt et al. (2008) \\
\hline Ephemerellidae & Generally CG. Some Sc. Few Sh. 1 Pr & Merritt et al. (2008) \\
\hline Euthyplociidae & CG & Merritt et al. (2008) \\
\hline Heptageniidae & Generally Sc. Facultative CG & Merritt et al. (2008) \\
\hline Isonychiidae & $\mathrm{Ft}, \mathrm{Pr}$ & Merritt et al. (2008) \\
\hline Leptohyphidae & Generally CG. A few Ft & Merritt et al. (2008) \\
\hline Leptophlebiidae & Generally CG. Facultative Sc and a few Ft & Baptista et al. (2006); Merritt et al. (2008) \\
\hline Melanemerellidae & $\mathrm{Sh}$ & Molineri \& Dominguez (2003) \\
\hline Nesameletidae & $\mathrm{Sc}$ & Hawking et al. (2013) \\
\hline Oligoneuriidae & Generally Ft & Baptista et al. (2006); Merritt et al. (2008) \\
\hline Oniscigastridae & CG & Hawking et al. (2013) \\
\hline Polymitarciidae & $\mathrm{CG}, \mathrm{Ft}$ & Merritt et al. (2008) \\
\hline Siphloneuridae & $\mathrm{CG}$ & Merritt et al. (2008) \\
\hline \multicolumn{3}{|l|}{ Odonata } \\
\hline Amphipterygidae & $\operatorname{Pr}$ & Merritt et al. (2008) \\
\hline Calopterygidae & $\operatorname{Pr}$ & Merritt et al. (2008) \\
\hline Coenagrionidae & $\operatorname{Pr}$ & Merritt et al. (2008) \\
\hline Dicteriadidae & $\operatorname{Pr}$ & Domínguez \& Fernández (2009) \\
\hline Megapodagrionidae & $\operatorname{Pr}$ & Merritt et al. (2008) \\
\hline Lestidae & $\operatorname{Pr}$ & Merritt et al. (2008) \\
\hline Perilestidae & $\operatorname{Pr}$ & Merritt et al. (2008) \\
\hline Polythoridae & $\operatorname{Pr}$ & Chará et al. (2012) \\
\hline Platystictidae & $\operatorname{Pr}$ & Merritt et al. (2008) \\
\hline Protoneuridae & $\operatorname{Pr}$ & Merritt et al. (2008) \\
\hline Pseudostigmatidae & $\operatorname{Pr}$ & Merritt et al. (2008) \\
\hline Synlestidae & $\operatorname{Pr}$ & Merritt et al. (2008) \\
\hline Aeshnidae & $\operatorname{Pr}$ & Merritt et al. (2008) \\
\hline Austropetaliidae & $\operatorname{Pr}$ & Domínguez \& Fernández (2009) \\
\hline Cordulegastridae & $\operatorname{Pr}$ & Merritt et al. (2008) \\
\hline Corduliidae & $\operatorname{Pr}$ & Merritt et al. (2008) \\
\hline Gomphidae & $\operatorname{Pr}$ & Merritt et al. (2008) \\
\hline Libellulidae & $\operatorname{Pr}$ & Merritt et al. (2008) \\
\hline Macromiidae & $\operatorname{Pr}$ & Merritt et al. (2008) \\
\hline Neopetaliidae & $\operatorname{Pr}$ & Domínguez \& Fernández (2009) \\
\hline Petaluridae & $\operatorname{Pr}$ & Domínguez \& Fernández (2009) \\
\hline \multicolumn{3}{|l|}{ Plecoptera } \\
\hline Austroperlidae & Sh & Domínguez \& Fernández (2009) \\
\hline Diamphipnoidae & Sc, Sh (Diamphipnoa Sc, Diamphipnopsis Sh) & Domínguez \& Fernández (2009) \\
\hline Eustheniidae & $\operatorname{Pr}$ & Domínguez \& Fernández (2009) \\
\hline Gripopterygidae & Sc, Sh, CG & Domínguez \& Fernández (2009) \\
\hline
\end{tabular}


CUADRO 1 (Continuación) / TABLE 1 (Continued)

\begin{tabular}{|c|c|c|}
\hline Family & Functional Feeding Group & Reference \\
\hline Notonemouridae & $\mathrm{Sc}$ & Domínguez \& Fernández (2009) \\
\hline Perlidae & $\operatorname{Pr}$ (early stages Dt) & Merritt et al. (2008) \\
\hline Blattodea & Unknown & \\
\hline \multicolumn{3}{|l|}{ Hemiptera } \\
\hline Belostomatidae & $\operatorname{Pr}$ & Domínguez \& Fernández (2009) \\
\hline Corixidae & Generally $\mathrm{Pc}-\mathrm{Hb}$, some Pr or Sc & Merritt et al. (2008) \\
\hline Gelastocoridae & $\operatorname{Pr}$ & Domínguez \& Fernández (2009) \\
\hline Gerridae & $\operatorname{Pr}$ & Domínguez \& Fernández (2009) \\
\hline Hebridae & $\operatorname{Pr}$ & Domínguez \& Fernández (2009) \\
\hline Helotrephidae & $\operatorname{Pr}$ & Domínguez \& Fernández (2009) \\
\hline Hydrometridae & $\operatorname{Pr}$ & Domínguez \& Fernández (2009) \\
\hline Leptopodidae & $\operatorname{Pr}$ & Domínguez \& Fernández (2009) \\
\hline Macroveliidae & $\operatorname{Pr}$ & Domínguez \& Fernández (2009) \\
\hline Mesoveliidae & $\operatorname{Pr}$ & Domínguez \& Fernández (2009) \\
\hline Naucoridae & $\operatorname{Pr}$ & Domínguez \& Fernández (2009) \\
\hline Nepidae & $\operatorname{Pr}$ & Domínguez \& Fernández (2009) \\
\hline Notonectidae & $\operatorname{Pr}$ & Domínguez \& Fernández (2009) \\
\hline Ochteridae & $\operatorname{Pr}$ & Domínguez \& Fernández (2009) \\
\hline Pleidae & $\operatorname{Pr}$ & Domínguez \& Fernández (2009) \\
\hline Potamocoridae & $\operatorname{Pr}$ & Domínguez \& Fernández (2009) \\
\hline Saldidae & $\operatorname{Pr}$ & Domínguez \& Fernández (2009) \\
\hline Veliidae & $\operatorname{Pr}$ & Domínguez \& Fernández (2009) \\
\hline \multicolumn{3}{|l|}{ Trichoptera } \\
\hline Anomalopsychidae & $\mathrm{Sc}$ & Jardim \& Nessimian (2011) \\
\hline Atriplectididae & $\operatorname{Pr}$ & Malicky (1997) \\
\hline Beraeidae & Probably CG & Merritt et al. (2008) \\
\hline Calamoceratidae & Generally Sh-Dt and Sc & Merritt et al. (2008) \\
\hline Ecnomidae & $\mathrm{Ft}$ ? & Merritt et al. (2008) \\
\hline Glosossomatidae & Generally obligate Sc & Merritt et al. (2008) \\
\hline Helicopsychidae & Obligate Sc & Merritt et al. (2008) \\
\hline Helicophidae & $\mathrm{CG}, \mathrm{Sh}$ & Wiggins (2004) \\
\hline Hydrobiosidae & $\operatorname{Pr}$ & Domínguez \& Fernández (2009) \\
\hline Hydropsychidae & Generally Ft. Some Pr and seasonal Sc & Merritt et al. (2008) \\
\hline Hydroptilidae & Generally Pc-Hb, Sc, CG & Merritt et al. (2008) \\
\hline Kokiriidae & $\operatorname{Pr}$ & Hawking et al. (2013) \\
\hline Lepidostomatidae & Obligate Sh-Dt & Merritt et al. (2008) \\
\hline Leptoceridae & $\begin{array}{l}\mathrm{CG} \text { and Ft, Sh-Hb, Sc, } \operatorname{Pr} \text { (Oecetis Pr, Facultative } \\
\text { Sh-Hb. Nectopsyche Sh-Hb, CG) }\end{array}$ & Merritt et al. (2008) \\
\hline Limnephilidae & $\begin{array}{l}\text { Generally Sh-Dt, Facultative Sh, Facultative CG, } \\
\text { some Sh-Hb. }\end{array}$ & Merritt et al. (2008) \\
\hline Odontoceridae & Generally Sh & Merritt et al. (2008) \\
\hline Philopotamidae & Generally obligate Ft & Merritt et al. (2008) \\
\hline Philorheithridae & $\operatorname{Pr}$ & Wiggins (2004) \\
\hline Polycentropodidae & $\begin{array}{l}\text { Generally Ft. Some facultative Pr. } \\
\text { Cernotina and Polycentropus } \operatorname{Pr}\end{array}$ & Merritt et al. (2008) \\
\hline Sericostomatidae & Generally Sh & Merritt et al. (2008) \\
\hline Stenopsychidae & Unknown & \\
\hline Tasimiidae & $\mathrm{Sc}$ & Wiggins (2004) \\
\hline
\end{tabular}


CUADRO 1 (Continuación) / TABLE 1 (Continued)

\begin{tabular}{|c|c|c|}
\hline Family & Functional Feeding Group & Reference \\
\hline Xiphocentronidae & CG & Merritt et al. (2008) \\
\hline \multicolumn{3}{|l|}{ Lepidoptera } \\
\hline Crambidae & $\begin{array}{l}\text { Generally } \mathrm{Sh}-\mathrm{Hb} \text { (Petrophila } \mathrm{Sc}, \text { Facultative } \mathrm{Sh}-\mathrm{Hb} \text {, } \\
\text { Neargyractis } \mathrm{Sh}-\mathrm{Hb})\end{array}$ & Merritt et al. (2008) \\
\hline Noctuidae & $\mathrm{Sh}-\mathrm{Hb}$ & Merritt et al. (2008) \\
\hline Tortricidae & $\mathrm{Sh}-\mathrm{Hb}$ & Merritt et al. (2008) \\
\hline \multicolumn{3}{|l|}{ Megaloptera } \\
\hline Corydalidae & $\operatorname{Pr}$ & Domínguez \& Fernández (2009) \\
\hline Sialidae & $\operatorname{Pr}$ & Domínguez \& Fernández (2009) \\
\hline \multicolumn{3}{|l|}{ Neuroptera } \\
\hline Osmylidae & $\operatorname{Pr}$ & Domínguez \& Fernández (2009) \\
\hline Sisyridae & $\operatorname{Pr}$ & Domínguez \& Fernández (2009) \\
\hline \multicolumn{3}{|l|}{ Mecoptera } \\
\hline Nannochoristidae & $\operatorname{Pr}$ & Domínguez \& Fernández (2009) \\
\hline \multicolumn{3}{|l|}{ Coleoptera } \\
\hline Chrysomelidae & Sh-Hb (L and A) & Merritt et al. (2008) \\
\hline Curculionidae & Sh-Hb (L and A) & Merritt et al. (2008) \\
\hline Gyrinidae & Generally $\operatorname{Pr}(\mathrm{L}$ and A) & Merritt et al. (2008) \\
\hline Noteridae & $\operatorname{Pr}, C G(L) . \operatorname{Pr}(A)$ & Merritt et al. (2008) \\
\hline Amphizoidae & $\operatorname{Pr}(\mathrm{L}$ and $\mathrm{A})$ & Merritt et al. (2008) \\
\hline Dytiscidae & Generally $\operatorname{Pr}(\mathrm{L}$ and $\mathrm{A})$ & Merritt et al. (2008) \\
\hline Dryopidae & Generally Sh-Hb (L). Generally Sc, Sh-Hb (A) & Merritt et al. (2008) \\
\hline Elmidae & Generally CG, Sc, Sh-Hb (L and A) & Merritt et al. (2008) \\
\hline Haliplidae & Generally Sh-Hb, Pc-Hb, some $\operatorname{Pr}(\mathrm{L}$ and A) & Merritt et al. (2008) \\
\hline Hydroscaphidae & $\mathrm{Sc}(\mathrm{L}$ and $\mathrm{A})$ & Merritt et al. (2008) \\
\hline Hydrophilidae & Generally Pr (L). Generally CG (A) & Merritt et al. (2008) \\
\hline Hydraenidae & $\operatorname{Pr}(\mathrm{L}) . \mathrm{Sc}, \mathrm{CG}(\mathrm{A})$ & Merritt et al. (2008) \\
\hline Lampyridae & $\operatorname{Pr}$ & Domínguez \& Fernández (2009) \\
\hline Lepiceridae & Unknown & \\
\hline Limnichidae & Generally CG? (L and A) & Merritt et al. (2008) \\
\hline Lutrochidae & Sh-Dt, $\mathrm{Hb}(\mathrm{L}$ and $\mathrm{A})$ & Merritt et al. (2008) \\
\hline Meruidae & Unknown & \\
\hline Ptilodactylidae & Generally Sh-Dt, Hb (L) & Merritt et al. (2008) \\
\hline Psephenidae & Sc (L) (Adult NonFeeding) & Merritt et al. (2008) \\
\hline Ptilidae & Sc (A) & Merritt et al. (2008) \\
\hline Scirtidae & Generally Sc, CG, Sh-Hb, Pc-Hb (L) & Merritt et al. (2008) \\
\hline Staphylinidae & $\mathrm{Pr}, \mathrm{CG}, \mathrm{Sh}-\mathrm{Hb}(\mathrm{A})$ & Merritt et al. (2008) \\
\hline \multicolumn{3}{|l|}{ Diptera } \\
\hline Athericidae & $\operatorname{Pr}$ & Merritt et al. (2008) \\
\hline Blephariceridae & Generally Sc & Merritt et al. (2008) \\
\hline Ceratopogonidae & Generally $\mathrm{Pr}$, some facultative CG and Sc & Merritt et al. (2008) \\
\hline Ceratopogoninae & Generally Pr, a few CG & Merritt et al. (2008) \\
\hline Forcipomyiinae & $\mathrm{CG}, \mathrm{Sc} ?$ & Merritt et al. (2008) \\
\hline Corethrellidae & $\operatorname{Pr}$ & Merritt et al. (2008) \\
\hline Culicidae & Generally Ft and CG & Merritt et al. (2008) \\
\hline Chironomidae & $\mathrm{CG}$ and $\mathrm{Ft}, \mathrm{Pr}$ & Merritt et al. (2008) \\
\hline Chironominae & Generally CG, Ft & Merritt et al. (2008) \\
\hline Diamesinae & Generally CG, Sc & Merritt et al. (2008) \\
\hline
\end{tabular}


CUADRO 1 (Continuación) / TABLE 1 (Continued)

\begin{tabular}{lll}
\multicolumn{1}{c}{ Family } & \multicolumn{2}{c}{ Functional Feeding Group } \\
Orthocladiinae & Generally CG, Sc & Merritt et al. (2008) \\
Podonominae & CG, Sc & Merritt et al. (2008) \\
Tanypodinae & Pr & Merritt et al. (2008) \\
Chaoboridae & Pr & Merritt et al. (2008) \\
Deuterophlebiidae & Obligate Sc & Merritt et al. (2008) \\
Dixidae & CG & Merritt et al. (2008) \\
Dolichopodidae & Generally Pr & Merritt et al. (2008) \\
Empididae & Generally Pr & Merritt et al. (2008) \\
Ephydridae & Generally CG, Sh-Hb, Sc, Pr & Merritt et al. (2008) \\
Muscidae & Generally Pr & Merritt et al. (2008) \\
Pelecorhynchidae & Pr, Sh-Hb? & Merritt et al. (2008) \\
Psychodidae & Generally CG (Maruina Sc, CG ) & Merritt et al. (2008) \\
Ptychopteridae & Generally Obligate CG & Merritt et al. (2008) \\
Sarcophagidae & CG & Merritt et al. (2008) \\
Simuliidae & Generally Obligate Ft, some Sc, Pr and facultative CG Merritt et al. (2008) \\
Sciomyzidae & Generally Pr & Merritt et al (2008) \\
Stratiomyidae & Generally CG & Merritt et al. (2008) \\
Syrphidae & CG & Generritt et al. (2008) \\
Tabanidae & Sc & Territt et al. (2008) \\
Thaumaleidae & Generally Sh-Dt, CG (Hexatoma Pr, Limonia Sh-Hb, Merritt et al. (2008) \\
Tipulidae & & \\
\hline
\end{tabular}

FFG classification must be made at the genus or species level and this list is a preliminary guide for those interested in working on the topic. The assignment of more than one FFG per family is the reflection of the diversity within a family. When most groups within a family belong to a few FFG, it is stated as "generally" or "some". A few families that completely lack information are listed as "unknown." Question marks (?) denote when the assignment is questionable. Updates to this list will be posted online (http://www.ramirezlab.net/research/ffg/).

$\mathrm{A}=$ Adult, $\mathrm{L}=$ Larvae, $\mathrm{CG}=$ Collectors-Gatherers, $\mathrm{Ft}=$ Filters, Pr=Predators, $\mathrm{Pc}=$ Piercers, Sh=Shredders, Sc=Scrapers. For some cases, trophic guild information is provided to clarify their functional role: $\mathrm{Dt}=\mathrm{Detritivores} ; \mathrm{Hb}=\mathrm{Herbivores}$. Thus, a $\mathrm{Sh}-\mathrm{Dt}$ is a shredder on plant detritus, not of live tissue; while a $\mathrm{Sh}-\mathrm{Hb}$ is a shredder on live plant tissue.

like lepidopteran larvae from the families Noctuidae and Tortricidae. Shredders of decomposing plant material (e.g., CPOM, Sh-Dt in Table 1) are detritivores and wood borers.

Organisms that consume living plant tissue are responsible for major herbivory losses by aquatic vascular plants. Chrysomelid beetles are known to specialize on vascular plants and some are used as biocontrols of floating vascular plants (Cronin, Schlacher, Lodge \& Siska, 1999). Shredders that consume detritus have received a great deal of attention by stream ecologists. There is a solid amount of evidence demonstrating the importance of macroinvertebrates as decomposers of dead plant material entering aquatic ecosystems (e.g., Webster \& Benfield, 1986; Gessner, 1999). There is also evidence that shredding macroinvertebrates increase the amount of fine particles in streams, while it remains unclear how important are these particles to insect collectors (Cuffney et al., 1990; Usio, Konishi \& Nakano, 2001).

Suggested translation to Spanish: fragmentadores.

Alternative uses of the term "Shredder" According to our definition, an organism can be considered a shredder if it cuts or breaks plant tissue particles while feeding. This is the same definition used by Cummins (1973) 
and Merritt, Craig, Wotton \& Walker (2008). However, several studies have used a more general definition by calling any organism that consumes leaf material a shredder regardless of their behavior. Snails provide a good example, their feeding behavior involves the use of a radula to remove tissue by scraping the substrates they are feeding on. According to the FFG definition that we are following here, snails are scrapers no matter what substrate they feed on because functionally they scrape the substrate. If a snail is feeding on a rock it will be likely consuming diatoms, bacteria, fungi and detritus. Individuals feeding over leaf substrates will be consuming plant detritus. Some studies called snails shredders, because their feeding accelerates plant breakdown (e.g., Mullholand, Elwood, Newbold \& Ferren, 1985), while other consider this a case where a scraper facilitates the process of organic matter breakdown (Lamberti, Gregory, Ashkenas, Steinman \& McIntire, 1989). One could argue either way, the important point is to clarify the use of the term before using it to avoid confusions.

Collectors: Collector or collector-gatherers are organisms with modified mouth parts to sieve or collect small particles $(<1 \mathrm{~mm})$ accumulated on the stream bottom. Similar to shredders, collectors can consume small pieces of leaves, but their mouth parts are not equipped to cut them into smaller pieces and only consume those that are small in size. Functionally, collectors play an important role re-packing FPOM into larger particles after they consume them.

Collectors are often abundant in stream ecosystems where they tend to be more common in areas with slow flow where fine particles are abundant. Several subfamilies of Chironomidae are collectors and also important prey for other consumers (Hershey, 1987). FPOM is often of poor quality in streams and collectors tend to consume large amounts of particles while feeding, thus having an important impact on particle size and quality (Heard \& Richardson, 1995). Particle consumption is only part of the function of collectors; their feeding behavior often results in small disturbances and re-suspension of particles to the water column, with the potential for downstream transport (Cross, Ramírez, Santana \& Silvestrini, 2008).

Suggested translation to Spanish: recolectores. We propose to avoid the translation of collector-gatherers as "colector-recolector," as both words are synonyms in Spanish.

Filterers: Filterers or collector-filterers are organisms with especial adaptations to capture particles directly from the water column. Adaptations include the construction of nets to filter water like those used by some Trichoptera larvae (e.g., Polycentropodidae) or the presence of modified mouth part structures like those present in Simuliidae.

The ecosystem function of this group is to remove particles from the water column and by doing so they reduce the export of particles to downstream reaches, making the ecosystem more efficient in the use of resources (Wotton, Malmqvist, Muotka \& Larsson, 1998). Particle types consumed by filterers are very diverse in size and composition. Some Trichoptera larvae are known to consume drifting animals as part of their diet. Thus, they are predators (as they consume animal tissue), but do so by filter feeding and functionally are considered filterers (Benke \& Wallace, 1980).

Suggested translation to Spanish: Filtradores.

Predators: Predators are organisms that consume other organisms using different strategies to capture them. Predators employ a diversity of strategies for capturing prey, including modified mouth parts and behavior. Although many predators have abundant and strong teeth for prey consumption, some are highly specialized. For example, the labium in Odonata is a highly modified and unique structure among aquatic insects (Ramírez, 2010). Similarly, some Hemiptera have modified mouth parts in the form of beaks that they use to inject poison into their prey and consume tissue (e.g., Notonectidae). Other Hemiptera have 
modified legs to capture prey (e.g., Nepidae and Belostomatidae; Mazzucconi, López Ruf \& Bachmann, 2009).

In the context of FFG, we exclude from this group those organisms that capture their prey by filter feeding. The function of predators is very important in ecosystems as they move energy and also have the potential to control the populations of other organisms (Oberndorfer, McArthur \& Barnes, 1984; Cooper, Walde \& Peckarsky, 1990).

Suggested translation to Spanish: Depredadores.

Organisms that belong to more than one FFG: Tropical ecosystems are inhabited by a diversity of organisms with unusual adaptations. Therefore, it is not surprising to find organisms that do not fit in a single FFG or perhaps that their behavior and function varies over space and time. Shrimps provide a clear example of multiple FFG in a single species. Atya lannipes (Atydae) have modified legs with multiple hairs that they use to consume FPOM. Individuals inhabiting slow water areas are collectors as they remove particles from the stream bottom. However, individuals inhabiting fast flowing riffles can use the same structures to filter feeding (Crowl, McDowell, Covich \& Johnson, 2001). Thus, one could assign this species to two possible FFGs depending on the habitat used and the behavior displayed by individuals. Similarly, crayfish in temperate streams are known to play more than one functional role and in studies of secondary production their productivity is often partitioned among several FFG (e.g., Lugthart \& Wallace, 1992). Other examples are likely to surface as we increase our understanding of tropical macroinvertebrates.

Species could also belong to more than one FFG if they undergo changes in behavior and feeding strategies along their life. Ontogenetic diet shifts are known in many organisms. In the case of aquatic insects, some stonefly species had been reported to consume detritus during early larval stages and slowly switch to animal tissue as the larvae mature (Céréghino, 2006).
Therefore, when examining insects to assign them to FFG, one must pay attention to possible differences among larval stages.

\section{A preliminary assignment of FFG for Latin American families}

Required information on morphology and behavior needed to assign FFG is particularly scarce for aquatic insects in tropical regions. For Latin America, there is enough detail to start assigning FFG to the families of aquatic insects in the region. Here we compiled a list of families of aquatic insects and their FFG assignment for Latin America using available information (Table 1). Family level assignment of FFG has clear limitations, as some families are very diverse and species within a family are likely to belong to different groups. Therefore, we advise readers to use this information with caution, as our goal is to provide a starting point for those interested in understanding the role of aquatic insects in ecosystem processes. Also, we hope this list will encourage others to conduct more specific studies so that a genus- or species-level list can be eventually completed.

Available information indicates that some families in Table 1 belong to a single FFG, while others are composed of species that play a variety of roles. We convey this by assigning them to more than one group. FFG were assigned using the best information available, but we expect changes in the list as additional information becomes available. In order to maintain this list useful, a working version is posted online to facilitate updates (http://www. ramirezlab.net/research/ffg/).

\section{How to assign FFG?}

FFGs are intended to reflect the function of organisms in their ecosystems and the way they consume resources. Therefore, assignment of FFG requires information on animal morphology and behavior. While gut content information is valuable in understanding the trophic position of a species, it is not necessary to assign them to FFG. 
Examination of the mouth parts and accessory structures in the front legs is a first step in assigning a FFG. These are the parts used by the organism to capture, manipulate, and consume food resources (Merritt, Cummins \& Berg, 2008). Sharp and pointed teeth are characteristics of predators and shredders. Modified mouth parts that look like plates or flat structures are an indication of a scraper. Collectors and filterers often have a large number of hairs and setae or fan-like structures to collect particles. Mouth parts often have to be observed in live insects to understand the proper location of each structure and their position relative to feeding substrates (Polegatto \& Froehlich, 2001). In addition to the shape and form, the feeding behavior must be described. Studies on feeding behavior often place live specimens in flow chambers with various food resources and quantitatively assess behavior (McShaffrey \& McCaffert, 1988). Observations and data collection are often facilitated by the use of filming equipment (Merritt et al., 1996; Polegatto \& Froehlich, 2003). There is an important amount of natural history observation into assigning FFG.

Gut content analysis will certainly provide information on resources eaten and thus one could infer the FFG. However, care must be taken no to assign groups solely on what it is found in the guts. For example, larvae of Hydropsychidae have chewing mouth parts reflecting to some degree those of a predator, they also spin nets to filter the water column and capture particles, and their guts are often full of Chironomidae head capsules (Benke \& Wallace, 1980). Thus, one could assign a Hydropsychidae to the predator group, but they are filterers as they prey upon drifting organisms (Benke \& Wallace, 1980; 1997).

FFG vs. Trophic guilds: As stated above, FFG reflect the functional role of organisms in their ecosystems and how their presence alters rates of ecosystem function. For example, the presence of insect shredders facilitate the breakdown of leaves, which is their functional role, whether or not they rely on leaves as a food resource is not central to assign their FFG. Assessing what food resources are used by organisms is relevant to studies focusing on questions related to trophic position and resource partitioning. We recommend the use of the trophic guild (gremios tróficos in Spanish) classification for studies focused in food resources. Trophic guilds are similar to FFG in that they could also consider behavior, but make emphasis on the type of resources consumed by organisms and their place in food webs (Blondel, 2003). The guild concept might include groups such as predators defined as organisms that consume animal tissue, herbivores or grazers those that consume primary producers, detritivores are those that consume decomposing organic matter (e.g., leaves and fine particles in streams), and omnivores as those that consume plant and animal resources (i.e., classical definition) or those that feed on more than one trophic level (i.e., food web theory definition). Simberloff \& Dayan (1991) review the concept of trophic guild and its importance in understanding community structure in general.

Case study: The value of incorporating morphological and behavioral information when assigning organisms to a FFG can be best appreciated with an example. As part of our ongoing studies in urban stream ecology in Puerto Rico, we have been analyzing organism's morphology, behavior and resource consumption. Larval Macrothemis, as all Odonata, have well developed mandibles and a modified labium for capturing prey. Their behavior is classified as "sit and way," in which the larvae wait without moving in a single place until potential prey swim by, and then they move quickly to capture it. Gut content analysis of 10 individuals of different sizes resulted in $40 \%$ animal tissue, $18 \%$ plant or algal tissue, $2 \%$ fungi, and $40 \%$ amorphous detritus. Analyzing this information, one can classify larval Macrothemis in different groups depending on the information used. Larval morphology and behavior will certainly indicate that they are predators. However, use of gut content 
information suggests some degree of omnivory and the amount of plant tissue might indicate herbivory. However, we clearly know that Odonata are predators and that plant material is likely the result of them consuming mayflies with guts full of diatoms, never that Odonata consume diatoms.

Trichoptera of the family Hydropsychidae provide another good example of the importance of using morphological and behavioral information when assigning FFG. Hydropsychidae are filter feeders, they spin nets using silk and build refuges where they hide while allowing their nets to passively capture potential food particles. Based on morphology and behavior this family is easily classified as Filterers. However, as stated above gut content analysis includes a wide range of particles with some of the larger species mostly consuming animals that are captured in their nets while drifting downstream. Benke \& Wallace (1980; 1997) found that chironomids are important food items for some species, accounting for most of their secondary production. Thus, based on gut content analysis, Hydropsychidae might be assigned to the trophic guild of predators and placed accordingly in stream food webs. However, their function is still to capture particles (including drifting animals) and making ecosystems more efficient in retaining energy.

\section{CONCLUSION}

FFG is a very useful tool when studying the role of aquatic macroinvertebrates in stream ecosystems. They provide valuable information on the function within ecosystem processes of particular organisms. Important advances in stream ecology have been possible by proper classification of macroinvertebrates into FFGs. The River Continuum Concept developed by Vannotte et al. (1980) is perhaps one of the best examples. As ecosystem function can be altered by a diversity of environmental factors, changes in FFG composition could also be used as an indicator of ecosystem change and recovery after disturbances.
At the same time, variability in the assignment of FFGs can also create confusion and hinder cross-site comparisons. Our goal in the present study was to help advance tropical studies by highlighting the importance of proper classification of FFGs. We also hope that our list of families will become obsolete in a near future, to be replaced by a more complete list to genus level resulting from new Latin American studies.

\section{ACKNOWLEDGMENTS}

We appreciate comments by Ricardo Albariño and an anonymous reviewer. A. Ramírez was partially funded by the Luquillo LTER during the writing of this manuscript (DEB-0620910).

\section{REFERENCES}

Barbee, N. C. (2005). Grazing insects reduce algal biomass in a neotropical stream. Hydrobiologia, 532, 153-165.

Baptista, D. F., Buss, D. F., Dias, L. G., Nessimian, J. L., Da Silva, E. R., De Moraes Neto, A. H. A., de Carvalho, S. N., De Oliveira, M. A., \& Andrade, L. R. (2006). Functional feeding groups of Brazilian Ephemeroptera nymphs: ultrastructure of mouthparts. Annales de Limnologie, 42, 87-96.

Benke, A. C., \& Wallace, J. B. (1980). Trophic basis of production among net-spinning caddisflies in a southern Appalachian stream. Ecology, 6, 108-118.

Benke, A. C., \& Wallace, J. B. (1997). Trophic basis of production among riverine caddisflies: implications for food web analysis. Ecology, 78, 1132-1145.

Blondel, J. (2003). Guilds or functional groups: does it matter? Oikos, 100, 223-231.

Céréghino, R. (2006). Ontogenetic diet shifts and their incidence on ecological processes: a case study using two morphologically similar stoneflies (Plecoptera). Acta Oecologica, 30, 33-38.

Chará-Serna, A. M., Chará, J. D., Zúñiga, M. d. C., Pedraza, G. X., \& Giraldo, L. P. (2010). Clasificación trófica de insectos acuáticos en ocho quebradas protegidas de la ecorregión cafetera Colombiana. Universitas Scientiarum, 15, 27-36.

Chará-Serna, A. M., Chará, J. D., Zuniga, M. d. C., Pearson, R. G., \& Boyero, L. (2012). Diets of leaf litterassociated invertebrates in three tropical streams. Annales de Limnologie, 48, 139-144. 
Chew, R. M. 1974. Consumers as regulators of ecosystems: an alternative to energetics. Ohio Journal of Sciences, 74, 359-370.

Cooper, S. D., Walde, S. J., \& Peckarsky, B. L. (1990). Prey exchange rates and the impact of predators on prey population in streams. Ecology, 71, 1503-1514.

Cronin, G., Schlacher, T., Lodge, D. M., \& Siska, E. L. (1999). Intraspecific variation in feeding preference and performance of Galerucella nymphaeae (Chrysomelidae: Coleoptera) on aquatic macrophytes. Journal of the North American Benthological Society, 18, 391-405.

Cross, W. F., Ramírez, A., Santana, A., \& Silvestrini, L. (2008). Toward separating the relative importance of invertebrate consumption and bioturbation in Puerto Rican streams. Biotropica, 40, 477-484.

Crowl, T. A., McDowell, W. H., Covich, A. P., \& Johnson, S. L. (2001). Freshwater shrimp effects on detrital processing and nutrients in a tropical headwater stream. Ecology, 82, 775-783.

Cuffney, T. F., Wallace, J. B. \& Lugthart, G. J. (1990). Experimental evidence quantifying the role of benthic invertebrates in organic matter dynamics of headwater streams. Freshwater Biology, 23, 281-299.

Cummins, K. W. (1973). Trophic relations of aquatic insects. Annual Review in Entomology, 18, 183-206.

Cummins, K. W., \& Klug, M. J. (1979). Feeding ecology of stream invertebrates. Annual Review in Ecology and Systematics, 10, 147-172.

Cummins, K. W., Wilzbach, M. A., Gates, D. M., Perry, J. B., \& Taliaferro, W. B. (1989). Shredders and riparian vegetation. BioScience, 39, 24-30.

Cummins, K. W., Merritt, R. W., \& Andrade, P. C. N. (2005). The use of invertebrate functional groups to characterize ecosystem attributes in selected streams and rivers in south Brazil. Studies of Neotropical Fauna and the Environment, 40, 69-89.

Díaz Villanueva, V., Albariño, R., \& Canhoto, C. (2012). Positive effect of shredders on microbial biomass and decomposition in stream microcosms. Freshwater Biology, 57, 2504-2513.

Domínguez, E., \& Fernández, H. R. (2009). Macroinvertebrados bentónicos sudamericanos. Tucumán: Fundación Miguel Lillo.

Feminella, J. W., \& C. P. Hawkins. (1995). Interactions between stream herbivores and periphyton: a quantitative analysis of past experiments. Journal of the North American Benthological Society 14, 465-509.

Gessner, M. O., Chauvet, E., \& Dobson, M. (1999). A perspective on leaf litter breakdown in streams. Oikos, $85,377-384$.

Hawking, J. H., Smith, L. M., \& Le Busque, K. (Eds.). (2013). Identification and Ecology of Australian
Freshwater Invertebrates. Murray-Darling Freshwater Research Centre. (retrieved from http:// www.mdfrc.org.au/bugguide, Version January 2009, Accessed August 10, 2013)

Heard, S., \& Richardson, J. S. (1995). Shredder-collector facilitation in stream detrital food webs: is there enough evidence? Oikos, 72, 359-366.

Hershey, A. E. (1987). Tubes and foraging behavior in larval Chironomidae: implications for predator avoidance. Oecologia, 73, 236-241.

Jackson, J. K., \& Sweeney, B. W. (1995). Egg and larval development times for 35 species of tropical stream insects from Costa Rica. Journal of the North American Benthological Society, 14, 115-130.

Jardim, G. A., \& Nessimian, J. L. (2011). A new species of Contulma Flint (Trichoptera, Anomalopsychidae) from southeastern Brazil. Revista Brasileira de Entomologia, 55(2), 226-228.

Lamberti, G. A., \& Resh, V. H. (1983). Stream periphyton and insect herbivores: An experimental study of grazing by a caddisfly population. Ecology, 64, 1124-1135.

Lamberti, G. A., Gregory, S. V., Ashkenas, L. R., Steinman, A. D., \& McIntire, C. D. (1989). Productive capacity of periphyton as a determinant of plant-herbivore interactions in streams. Ecology, 70, 1840-1856.

Lock, M., Costerton, J., Ventullo, R., Wallace, R., \& Charlton, S. (1984). River epilithon: toward a structuralfunctional model. Oikos, 42, 10-22.

Lugthart, G. J. \& Wallace, J. B. (1992). Effects of disturbance on benthic functional structure and production in mountain streams. Journal of the North American Benthological Society, 11, 138-164.

Mazzucconi, S. A., López Ruf, M. L., \& Bachmann, A. O. (2009). Hemiptera-Heteroptera: Gerromorpha y Nepomorpha. In E. Domínguez \& H. R. Fernández (Eds.), Macroinvertebrados bentónicos sudamericanos (pp. 167-231). Tucumán: Fundación Miguel Lillo.

McShaffrey, D., \& McCafferty, W. P. (1988). Feeding Behavior of Rhithrogena pellucida (Ephemeroptera:Heptageniidae). Journal of the North American Benthological Society, 7, 87-99.

Merritt, R. W., \& Cummins, K. W. (1978). An introduction to the aquatic insects of North America. Iowa: Kendall/Hunt Publishing Company.

Merritt, R. W., Craig, D. A., Wotton, R. S., \& Walker, E. D. (1996). Feeding Behavior of Aquatic Insects: Case Studies on Black Fly and Mosquito Larvae. Invertebrate Biology, 115, 206-217.

Merritt, R. W., Cummins, K. W., \& Berg, M. (Eds.). (2008). An introduction to the aquatic insects of North America. Iowa: Kendall/Hunt Publishing Company. 
Molineri C. \& Dominguez E. (2003). Nymph and egg of Melanemerella brasiliana (Ephemeroptera: Ephemerelloidea: Melanemerellidae), with comments on its systematic position and the higher classification of Ephemerelloidea. Journal of the North American Benthological Society 22(2): 263-275.

Mulholland, P. J., Elwood, J. W., Newbold, J. D., \& Ferren, L. A. (1985). Effect of a leaf-shredding invertebrate on organic matter dynamics and phosphorus spiralling in heterotrophic laboratory streams. Oecologia, 66, 199-206.

Oberndorfer, R. Y., McArthur, J. V., \& Barnes, J. R. (1984). The effects of invertebrate predators on leaf litter processing in an alpine stream. Ecology, 65, 1325-1331.

Palmer, C., Palmer, A., O’ Keeffe, J., \& Palmer, R. (1994). Macroinvertebrate community structure and altitudinal changes in the upper reaches of a warm temperate southern African river. Freshwater Biology, 32, 337-347.

Polegatto, C. M., \& Froehlich, C. G. (2001). Functional morphology of the feeding apparatus of the nymph of Farrodes sp. (Ephemeroptera: Leptophlebiidae). Acta Zoologica, 82, 165-175.

Polegatto, C. M., \& Froehlich, C. G. (2003). Feeding strategies in Atalophlebiinae (Ephemeroptera: Leptophlebiidae), with considerations on scraping and filtering. In Gaino E. (Ed). Research update on Ephemeroptera \& Plecoptera (pp. 55-61). Perugia: Università di Perugia.

Ramírez, A., \& Pringle, C. M. (1998). Structure and production of a benthic insect assemblage in a Neotropical stream. Journal of the North American Benthological Society, 17, 443-463.

Ramírez, A. 2010. Odonata. Revista de Biología Tropical, 58(Suppl. 4), 97-136.

Simberloff, D., \& Dayan, T. (1991). The guild concept and the structure of ecological communities. Annual Review of Ecology and Systematics, 22, 115-143.

Springer, M., Ramírez, A., \& Hanson, P. (2010). Macroinvertebrados de agua dulce de Costa Rica I. Revista de Biología Tropical, 58(Suppl. 4), 1-200.
Swanson, A. K., Hrinda, S., \& Keiper, J. B. (2007). Laboratory assessment of altered atmospheric carbon dioxide on filamentous green algae phenolic content and caddisfly growth and survival. Journal of Freshwater Ecology, 22, 49-60.

Tomanova, S., Goitia, E., \& Helesic, J. (2006). Trophic levels and functional feeding groups of macroinvertebrates in neotropical streams. Hydrobiologia, 556, 251-264.

Usio, N., Konishi, M., \& Nakano, S. (2001). Is invertebrate shredding critical for collector invertebrates? A test of the shredder-collector facilitation hypothesis. Ecological Research, 16, 319-326.

Vanni, M. J. (2002). Nutrient cycling by animals in freshwater ecosystems. Annual Review of Ecology and Systematics, 33, 341-370.

Vannote, R. L., Minshall, G. W., Cummins, K. W., Sedell, J. R., \& Cushing, C. E. (1980). The river continuum concept. Canadian Journal of Fisheries and Aquatic Sciences, 37, 130-137.

Wallace, J. B., Webster, J. R., \& Cuffney, T. F. (1982). Stream detritus dynamics: Regulation by invertebrate consumers. Oecologia, 53, 197-200.

Wallace, J. B. \& Webster, J. R. (1996). The role of macroinvertebrates in stream ecosystem function. Annual Review of Ecology and Systematics, 41, 115-139.

Webster, J. R. \& Benfield, E. F. (1986). Vascular plant breakdown in freshwater ecosystems. Annual Review of Ecology and Systematics, 17, 567-594.

Wiggins, G. B. (2004). Caddisflies, the Underwater Architects. Toronto: University of Toronto Press.

Wisely, B. (1961). Studies on Ephemeroptera 1. Coloburiscus humeralis (Walker); early life history and nymph. Transactions of the Royal Society of New Zealand Zoology, 1, 249-257.

Wotton, R. S., Malmqvist, B., Muotka, T., \& Larsson, K. (1998). Fecal pellets from a dense aggregation of suspension-feeders in a stream: An example of ecosystem engineering. Limnology and Oceanography, 43, 719-725. 
